\title{
Differential regeneration of artificial lesions among sympatric morphs of the Caribbean corals Porites astreoides and Stephanocoenia michelinii
}

\author{
I. Nagelkerken ${ }^{1,2,3, *}$, R. P. M. Bak ${ }^{1,3}$ \\ ${ }^{1}$ Institute for Systematics and Population Biology, University of Amsterdam, Mauritskade 61, PO Box 94766, 1090 GT Amsterdam, The Netherlands \\ ${ }^{2}$ Carmabi Foundation, PO Box 2090, Piscaderabaai z/n, Curaçao, Netherlands Antilles \\ ${ }^{3}$ Netherlands Institute for Sea Research, PO Box 59, 1790 AB Den Burg, Texel, The Netherlands
}

\begin{abstract}
Regeneration of artificial lesions was studied as an ecophysiological character in 2 morphs of Porites astreoides and Stephanocoenia michelinii to contribute to a better understanding of their presently unclear taxonomic status. As a reference, regeneration was also studied in 3 species/ morphs of Madracis. $P$. astreoides consists of a green and a brown morph, while $S$. michelinii consists of an encrusting morph with widely spaced corallites and a massive morph with compacted polyps. Regeneration was significantly faster in the green $P$. astreoides and in the encrusting $S$. michelinit No significant differences were found among the Madracis species/morphs. The energy required for faster regeneration in the 2 morphs was apparently not generated as a result of elevated densities of zooxanthellae or chlorophyl $a$. The green $P$. astreoides which occurs at more shallow depths, and perhaps also the encrusting $S$. michelinii, may be better adapted to the increased disturbances at shallow depths by means of, among other things, faster regeneration of lesions.
\end{abstract}

KEY WORDS: Regeneration - Lesions - Corals · Differentiation . Porites astreoides -Stephanocoenia michelini- Madracis

The taxonomic status of scleractinian corals has mostly been based on skeletal features such as growth form and microstructural characteristics (e.g. Wells 1956). Most corals, however, display a high degree of morphological variation. This variation may occur in corallites within a colony, within different parts of a single colony, between colonies within the same biotope, between environmental zones, or within regions (Veron 1995).

Lang (1984) therefore suggested also studying nonskeletal traits, such as sexual and asexual reproduc-

\footnotetext{
•E-mail: inagelk@ibm.net
}

tion, external and internal morphology, behavior, ecology (e.g. non-scleractinian associates, distribution), and physiology (environmental tolerance limits), to distinguish closely related species when skeletal features fail to reveal differences. A multi-character approach is even more favored, because when a consistent pattern is found in several characters, debate over the adequacy of a particular characteristic as a taxonomic tool becomes less important (Weil \& Knowlton 1994). This approach is now being used more often than before, and is frequently based on a combination of genetic and ecological or physiological characteristics (e.g. Ayre et al. 1991, Gattuso et al. 1991, Weil 1992, Potts et al. 1993, Van Veghel 1994, Weil \& Knowlton 1994, Takabayashi \& Hoegh-Guldberg 1995).

The 2 Caribbean corals Porites astreoides (Lamarck) and Stephanocoenia michelinii (Milne-Edwards and Haime) both possess at least 2 morphs which can be visually distinguished in situ. $P$. astreoides consists of a green (i.e. yellow-green to dark green; in Curaçao this morph is yellow-green) and a brown morph (i.e. light to dark brown) (Gleason 1993). S. michelinü consists of an encrusting morph with widely spaced corallites, and a massive morph with compacted polyps (see pictures in Humann 1994, p. 110-111). The encrusting morph is light-brown in colour and most of the pigment is restricted to the corallites, giving the coenosarc a pale-white appearance. The massive morph forms dome-shaped colonies and is green-brown in colour.

Some studies have found genetic, morphological or physiological differences between the Porites astreoides morphs (Gleason 1993, Potts et al. 1993), while others found no differences (Weil 1992). Very little 
attention has been paid to the morphs of Stephanocoenia michelinii. Scatterday (1974) mentioned a modification of growth in this and other coral species with depth or decreased light intensities, resulting in colonies with a lower corallite density and an increase in surface area of the coenosteum. Apparently, the taxonomic status of the $P$. astreoides and $S$. michelinii morphs remains unclear.

In this study we used the regeneration of artificial lesions as an ecophysiological character (see also Van Veghel \& Bak 1994) to contribute to a better understanding of the presently unclear taxonomic status of the Porites astreoides and Stephanocoenia michelinii morphs

Materials and methods. Colonies of Porites astreoides and Stephanocoenia michelinii morphs were selected haphazardly at Carmabi buoy 1 on the southwestern coast of Curaçao, Netherlands Antilles, at a depth of 5 to $7 \mathrm{~m}$ (light extinction coefficient $k=-0.117$ $\mathrm{m}^{-1}$; Bosscher \& Meesters 1992). Artificial lesions were inflicted on 18 green $P$. astreoides, 15 brown $P$. astreoides, 7 massive $S$ michelinii, and 9 encrusting $S$. michelinii colonies. On top of each colony a small artificial lesion was drilled using a hand-held drill equipped with a $2 \mathrm{~mm}$ steel bit. This resulted in cylindrical lesions with a diameter and depth of approximately $2 \mathrm{~mm}$.

The initial lesion perimeter, determined with macrophotography, and the initial lesion depth, measured with a Vernier caliper, were used to calculate the total initial lesion area. Initial lesion sizes (mean $\pm \mathrm{SD}$ ) for the 4 morphs were: $15.1 \pm 0.7 \mathrm{~mm}^{2}$ for the green Porites astreoides, $13.7 \pm 1.0 \mathrm{~mm}^{2}$ for the brown P. astreoides, $16.1 \pm 0.7 \mathrm{~mm}^{2}$ for the massive Stephanocoenia michelinii and $15.1 \pm 0.9 \mathrm{~mm}^{2}$ for the encrusting $S$. michelinii. Tissue recovery following lesion infliction was determined over a time period of $9 \mathrm{~d}$ in $P$. astreoides and $21 \mathrm{~d}$ in $S$. michelinii, during December 1996. At each measuring interval (2 to $3 \mathrm{~d}$ ) the progress of tissue recovery along the vertical lesion wall and lesion bottom was measured. The regeneration of the lesions is quantified as the mean percent of the total lesion area (i.e. $t_{0}$ ) recovered versus time.

For each lesion, the regression slope was calculated for the curve of lesion size versus time. Although this curve was exponential when the mean lesion size was depicted versus time (see Fig. 1), the curve was linear for individual lesions (mean $\mathrm{r}^{2}$ per species $>0.83$ ). The slopes were calculated using least squares linear regression and were compared between species with a 1-way ANOVA or Mann-Whitney $U$-test (Sokal \& Rohlf 1995). All analyses were performed with the program SYSTAT (SYSTAT 1992).

To interpret differences in regeneration among the Porites astreoides and Stephanocoenia michelinii
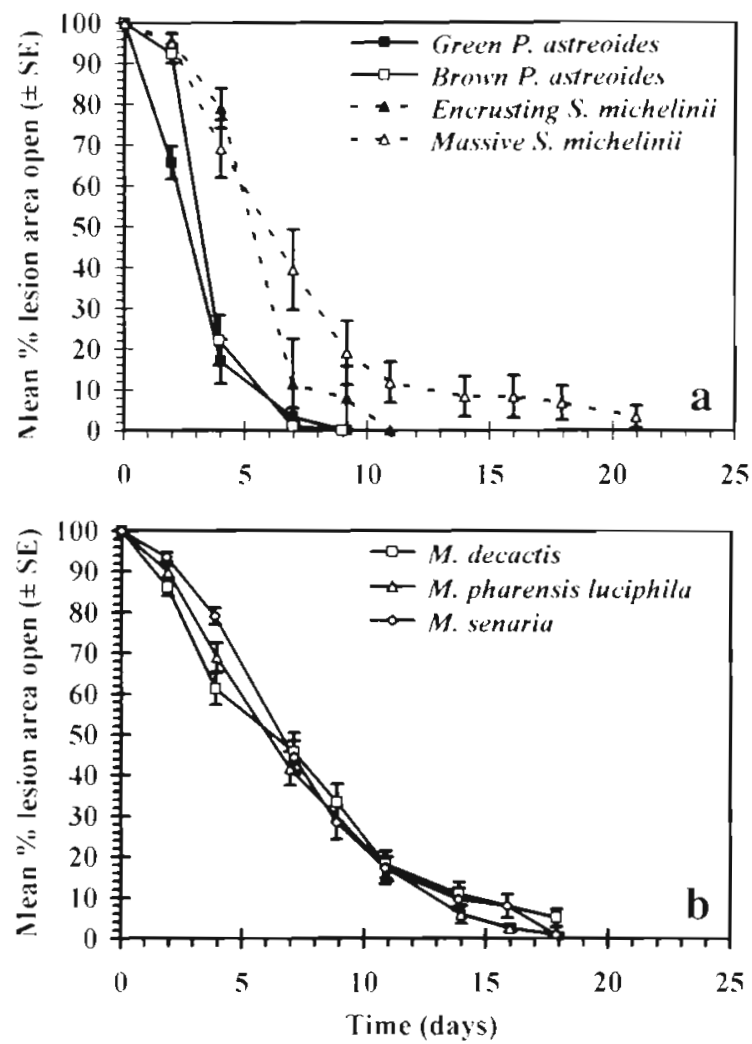

Fig. 1. (a) Regeneration of artificial lesions as a function of time for 2 morphs of Porites astreoides and Stephanocoenia michelinii. (b) Regeneration of artificial lesions as a function of time for 3 species/morphs of Madracis

morphs, the experiment was repeated in 3 species/ morphs of Madracis, which served as a reference for differences between species/morphs within 1 genus. This genus also has species/morphs with relatively small polyps, and colonies occur in the same depth range as $P$. astreoides and $S$. michelinii. During October-November 1996, artificial lesions were inflicted on $27 \mathrm{M}$. decactis (Lyman), $29 \mathrm{M}$. pharensis luciphila (Heller) and $31 \mathrm{M}$. senaria (Wells) colonies (see key to species of Madracis in Wells 1973a, b).

At the end of the regeneration experiment a small tissue sample $(\mathrm{ca} 0.5 \times 1.0 \mathrm{~cm}$ ) near the lesion was collected from each colony. Zooxanthellae and chlorophyll a densities were determined as in Szmant \& Gassman (1990).

Results. Differences in regeneration between the 2 morphs of Porites astreoides were observed during the first $4 \mathrm{~d}$ following lesion infliction (Fig. 1a). The mean regression slope of the green $P$, astreoides was significantly higher ( $p=0.005$, Mann-Whitney $U$-test) compared to that of the brown morph (Fig. 2). Nonetheless, all lesions had closed after $9 \mathrm{~d}$ in both morphs (Fig. 1a).

In an earlier experiment, during February-March 1993, the regeneration of larger lesions (diameter = 
$1 \mathrm{~cm}$ ) was studied in Porites astreoides at a depth of $5 \mathrm{~m}$ at the Seaquarium reef (I. Nagelkerken, E. H. Meesters \& R. P. M. Bak unpubl.). During this experiment the colour of the morphs was noted but no distinction was made during data analysis. Later recalculation of the data, however, also showed a significantly steeper mean regression slope ( $p=0.049$, Mann-Whitney $U$-test) for the green morph [slope = $-0.066 \pm 0.010$ (SE), $n=19$ ] than for the brown morph $($ slope $=-0.037 \pm 0.014, n=6)$.

Differences in lesion closure between the 2 morphs of Stephanocoenia michelinii were observed after the first $4 \mathrm{~d}$ following lesion infliction (Fig. 1a). The mean regression slope for the encrusting $S$. michelinii was significantly steeper $\left(F_{1,14}=9.576, p=0.008\right.$, 1 -way ANOVA) than for the massive morph (Fig. 2). The difference in regeneration between the 2 morphs was also expressed as a difference between the number of lesions closed at the end of the experiment. All lesions in the encrusting morph were closed after $11 \mathrm{~d}$, while lesion closure in the massive morph took more than 21 d (Fig. 1a).

In contrast to the Porites astreoides and Stephanocoenia michelinii morphs, the regeneration of lesions in the 3 Madracis species/morphs was similar (Fig. 1b). No significant difference ( $p>0.942,1$-way ANOVA and Tukey HSD test) was found between the mean regression slopes of $M$. decactis, $M$. pharensis luciphila and $M$. senaria (Fig. 2). The variation in the percentage of lesions closed among the 3 species/morphs was small, and most lesions were closed after $18 \mathrm{~d}$.

Neither the zooxanthellae nor chlorophyll a densities varied significantly among the morphs of Porites astreoides and Stephanocoenia michelinii (Table 1).

Discussion. This study shows that the regeneration of artificial lesions differed significantly among the

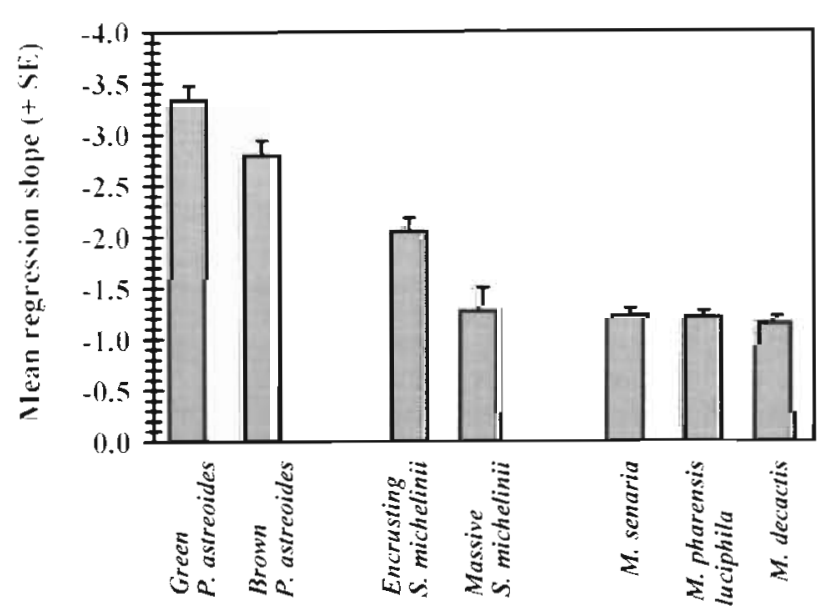

Fig. 2. Regression slopes of lesion recovery (lesion size vs time) for the different morphs of Porites astreoides and Stephanocoenia michelinii and species/morphs of Madracis
Table 1. Mean zooxanthellae and chlorophyll a densities of Porites astreoides and Stephanocoenia michelinii morphs

\begin{tabular}{|lcc|}
\hline & $\begin{array}{c}\text { Zooxanthellae } \\
\left(\mathrm{cm}^{-2}\right)\end{array}$ & $\begin{array}{c}\mathrm{Chl} a \\
\left(\mu \mathrm{cm}^{-2}\right)\end{array}$ \\
\hline Green P. astreoides & $3.1 \pm 0.2 \times 10^{6}$ & $7.7 \pm 1.2$ \\
Brown P. astreoides & $3.1 \pm 0.3 \times 10^{6}$ & $7.5 \pm 0.9$ \\
p-value (1-way ANOVA) & 0.962 & 0.896 \\
Encrusting S. michelinii & $40 \pm 0.4 \times 10^{6}$ & $7.9 \pm 0.9$ \\
Massive S. michelinii & $3.3 \pm 0.3 \times 10^{6}$ & $5.1 \pm 1.4$ \\
p-value (1-way ANOVA) & 0.225 & 0.093 \\
\hline
\end{tabular}

Porites astreoides and Stephanocoenia michelinii morphs. There is no conclusive data yet on the taxonomic status of the colour morphs of $P$. astreoides. Weil (1992) did not find any significant genetic or morphological variation between the 2 morphs. Likewise, Potts et al. (1993) did not find any differences in morphometric data. Other studies, however, did find differences between the 2 morphs. Fusion only occurs in colonies of similar colour (in Gleason 1993), while Potts et al. (1993) found a difference in allele frequencies between the 2 colour morphs. Furthermore, Gleason (1993) found a difference in both their vertical distribution and resistance to ultraviolet radiation. Although no morphological differences have yet been found and the genetic variation is unclear, the present study shows an ecological difference among the $P$. astreoides and $S$. michelinii morphs.

Scatterday (1974) reported a modification of growth in Stephanocoenia michelinii and other coral species with water depth. He observed that colonies living under reduced light conditions had larger corallites which were spaced wider apart. The existence of the 2. S. michelinii morphs cannot be attributed to this phenomenon, however. The corallites of the encrusting morph showed a similar modification in corallite spacing, but we observed this morph to be more abundant in shallow water. It is surprising that so little attention has been paid to these 2 morphs. The present study shows a differentiation in regeneration between the 2 morphs and care should therefore be taken when interpreting data from studies which have not separated these 2 morphs

It is known that at the species level corals commonly show differences in regeneration (Bak \& Steward-Van Es 1980, Meesters et al. 1992, Meesters \& Bak 1993 Bak \& Meesters 1997) and it is striking that there are differences between the Porites astreoides and Stephanocoenia michelinii morphs and not between the species/morphs of Madracis. This result is even more surprising as our experimental lesions were relatively small, and small lesions are less likely to show differentiation in regeneration rate than large ones 
(Meesters et al. 1997). Large lesion regeneration may still show differences within Madracis, but our results with small lesions emphasize the significant difference between the $P$, astreoides and $S$. michelinii morphs. This relatively large difference in an important ecophysiological character highlights a distance between morphs of $P$. astreoides and $S$. michelinii.

Van Veghel \& Bak (1994) studied regeneration in 3 morphs of the Montastrea annularis complex in an attempt to determine their taxonomic status and found that one of the morphs (bumpy or Montastrea franksi; Weil \& Knowlton 1994) regenerated faster than the other. Weil \& Knowlton (1994) regard the morphs as 3 species, based on a multi-character analysis. This underscores the use of regeneration in the evaluation of taxonomic distinction.

The differences in regeneration among the Porites astreoides and Stephanocoenia michelinii morphs cannot be explained by a difference in their zooxanthellae and chlorophyll a densities. Energy budgets of corals are often limited, and energy is partitioned over important processes such as respiration, growth, reproduction and regeneration (Bak 1983, Edmunds \& Spencer Davies 1986, Spencer Davies 1991). Regeneration of tissue requires, apart from nutrients acquired through heterotrophic feeding, a considerable amount of energy which must be supplied by the polyps surrounding and in the vicinity of the lesion (Meesters et al. 1994, 1997, Oren et al. 1997). The energy available to polyps often largely originates from the symbiotic algae in the host tissue (Muscatine et al. 1984). Faster regeneration in the green $P$. astreoides and in the encrusting $S$. michelinii requires more energy, but this is apparently not generated as a result of elevated densities of symbiotic cells or chlorophyll a pigments. Likewise, Takabayashi \& Hoegh-Guldberg (1995) found different growth rates in 2 colour morphs of Pocillopora damicornis, but no difference in their zooxanthellae densities.

The extra energy required for faster regeneration could be generated to the detriment of other physiological processes (e.g. Bak 1983, Meesters et al. 1994, Van Veghel \& Bak 1994). In this study the effects on other processes were not investigated. Gleason (1993) found significantly higher concentrations of mycosporine-like amino acids (MAAs) in the green Porites astreoides compared to the brown morph. He showed, however, that the higher metabolic cost of production of specific MAAs was not to the detriment of growth and protein content in the green morph.

Aside from a potential difference among morphs in the allocation of energy to physiological processes, 3 other possibilities may explain a difference in energy supply. They are: different species of zooxanthellae (Rowan et al. 1997) which have a different rate of photosynthesis or translocation of photosynthetic energy to the coral; a difference in the rate and type of zooplankton captured (Wellington 1982, Sebens et al. 1996); or a difference in the storage or translocation of lipids (Stimson 1987, Harland et al. 1993). The possibility exists that such physiological traits which are strongly linked to the regenerative abilities are not fully independent among the morphs, but are linked to the specific colony colour and morphology of the morphs. For example, in Porites astreoides morphs, the difference in the animal pigmentation may lead to different light levels in the zooxanthellae, while in Stephanocoenia michelinii morphs the different colony morphology may lead to a difference in particle capture. Thus, even though the morphs occur in the same environment, differences in morphology and colour may lead to a different physiological response between the morphs, resulting in the observed differentiation in regeneration.

The morphs which show the fastest regeneration (i.e. the green Porites astreoides and the encrusting Stephanocoenia michelinilj also occur at shallower depths (Gleason 1993, authors' pers. obs.). Considering this and the higher concentration of MAAs in the green morph (Gleason 1993), it is possible that the green $P$. astreoides, and perhaps also the encrusting $S$. michelinii, are better adapted to the environmental conditions in shallow water. In shallow water, increased stresses and disturbances often exists as a result of, for example, elevated UV radiation levels and increased sedimentation rates. Thus, the shallower-occurring green $P$. astreoides is able to protect itself against the increased UV radiation through a higher production of MAAs (Gleason 1993), while a higher regeneration rate (this study) may be a strategy for coping with the increase in the number of naturally occurring lesions in shallow water.

Acknowledgements. We thank the Carmabi Foundation for logistical support and F. Isabella for assistance in the field. This research was funded by the Department of Biology of the University of Amsterdam. This is NIOZ publication 3239. The manuscript benefited from the comments and suggestions of 4 anonymous reviewers.

\section{LITERATURE CITED}

Ayre DJ, Veron JEN, Dufty SL (1991) The corals Acropora palifera and Acropora cuneata are genetically and ecologically distinct. Coral Reefs 10:13-18

Bak RPM (1983) Neoplasia, regeneration and growth in the reef-building coral Acropora palmata. Mar Biol 77: 221-227

Bak RPM, Meesters EH (1997) Coral diversity, populations and ecosystem functioning. Proc 6th Int Conf Coel Biol Nationaal Natuur-Historisch Museum, Leiden, p 27-38

Bak RPM, Steward-Van Es Y (1980) Regeneration of superficial damage in the scleractinian corals Agaricia agaricites f. purpurea and Porites astreoides. Bull Mar Sci 30: $883-887$ 
Bosscher H, Meesters E (1992) Depth related changes in the growth of Montastrea annularis. Proc 7 th Int Coral Reef Symp 1:507-512

Edmunds PJ, Spencer Davies P (1986) An energy budget for Porites porites (Scleractinia). Mar Biol 92:339-347

Gattuso JP, Pichon M, Jaubert J (1991) Physiology and taxonomy of scleractinian corals: a case study in the genus Stylophora. Coral Reefs 9:173-182

Gleason DF (1993) Differential effects of ultraviolet radiation on green and brown morphs of the Caribbean coral Porites astreoides. Limnol Oceanogr 38:1452-1463

Harland AD, Navarro JC, Spencer Davies P, Fixter LM (1993) Lipids of some Caribbean and Red Sea corals: total lipid, wax esters, triglycerides and fatty acids. Mar Biol 117: $113-117$

Humann P (1994) Reef coral identification. Florida Caribbean Bahamas. New World Publications Inc, Jacksonville, FL

Lang JC (1984) Whatever works: the variable importance of skeletal and of non-skeletal characters in scleractinian taxonomy. Paleontogr Am 54:18-44

Meesters EH, Bak RPM (1993) Effects of coral bleaching on tissue regeneration potential and colony survival. Mar Ecol Prog Ser 96:189-198

Meesters EH, Bos A, Gast GJ (1992) Effects of sedimentation and lesion position on coral tissue regeneration. Proc 7 th Int Coral Reef Symp 2:681-688

Meesters EH, Noordeloos M, Bak RPM (1994) Damage and regeneration: links to growth in the reef-building coral Montastrea annularis. Mar Ecol Prog Ser 112:119-128

Meesters EH, Pauchli W, Bak RPM (1997) Predicting regeneration of physical damage on a reef-building coral by regeneration capacity and lesion shape. Mar Ecol Prog Ser 146:91-99

Muscatine L, Falkowski PG, Porter JW, Dubinsky Z (1984) Fate of photosynthetic fixed carbon in light- and shadeadapted colonies of the symbiotic coral Stylophora pistillata. Proc R Soc Lond B 222:181-202

Oren U, Benayahu Y, Loya Y (1997) Effect of lesion size and shape on regeneration of the Red Sea coral Favia favus. Mar Ecol Prog Ser 146:101-107

Potts DC, Budd AF, Garthwaite RL (1993) Soft tissue vs. skeletal approaches to species recognition and phylogeny reconstruction in corals. Cour Forschungsinst Senckenb 164:221-231

Rowan R, Knowlton N, Baker A, Jara J (1997) Landscape ecology of algal symbionts creates variation in episodes of coral bleaching. Nature 388:265-269

Scatterday JW (1974) Reefs and associated coral assemblages off Bonaire, Netherlands Antilles, and their bearing on Pleistocene and recent reef models. Proc 2nd Int Coral Reef Symp 2:85-106

Editorial responsibility: Otto Kinne (Editor),

Oldendorf/Luhe, Germany
Sebens KP, Vandersall KS, Savina LA, Graham KR (1996) Zooplankton capture by two scleractinian corals, Madracis mirabilis and Montastrea cavernosa, in a field enclosure. Mar Biol 127:303-317

Sokal RR, Rohlf FJ (1995) Biometry, 3rd edn. WH Freeman and Company, New York

Spencer Davies P (1991) Effect of daylight variations on the energy budgets of shallow-water corals. Mar Biol 108: $137-144$

Stimson JS (1987) Location, quantity and rate of change in quantity of lipids in tissue of Hawaiian hermatypic corals Bull Mar Sci 41:889-904

SYSTAT (1992) Statistics, version 5.2 edn. SYSTAT, Inc, Evanston, IL

Szmant AM, Gassman NJ (1990) The effects of prolonged 'bleaching' on the tissue biomass and reproduction of the reef coral Montastrea annularis. Coral Reefs 8: $217-224$

Takabayashi M, Hoegh-Guldberg O (1995) Ecological and physiological differences between two colour morphs of the coral Pocillopora damicornis. Mar Biol 123:705-714

Van Veghel MLJ (1994) Polymorphism in the Caribbean reef building coral Montastrea annularis. PhD thesis, University of Amsterdam

Van Veghel MLJ, Bak RPM (1994) Reproductive characteristics of the polymorphic Caribbean reef building coral Montastrea annularis. III. Reproduction in damaged and regenerating colonies. Mar Ecol Prog Ser 109:229-233

Veron JEN (1995) Corals in space and time. The biogeography \& evolution of the Scleractinia. Cornell University Press, New York

Weil E (1992) Genetic and morphological variation in Caribbean and Eastern Pacific Porites (Anthozoa, Scleractinia). Preliminary results. Proc 7 th Int Coral Reef Symp 2: 643-656

Weil E, Knowlton N (1994) A multi-character analysis of the Caribbean coral Montastrea annularis (Ellis and Solander, 1786) and its two sibling species, $M$. faveolata (Ellis and Solander, 1786) and M. franksi (Gregory, 1895). Bull Mar Sci 55:151-175

Wellington GM (1982) An experimental analysis of the effects of light and zooplankton on coral zonation. Oecologia 52: $311-320$

Wells JW (1956) Scleractinia. In: Moore RC (ed) Treatise on invertebrate paleontology. Coelenterata. Geological Society of America and University of Kansas Press, Lawrence, p $328-444$

Wells JW (1973a) New and old scleractinian corals from Jamaica. Bull Mar Sci 23:16-58

Wells JW (1973b) Two new hermatypic scleractinian corals from the West Indies. Bull Mar Sci 23:925-932

Submitted: August 4, 1997, Accepted: January 14, 1998

Proofs received from author(s): February 13, 1998 